\title{
New information on Oelandia (Mollusca) from the Middle Cambrian of Sweden
}

\author{
JOHN S. PEEL AND ELLIS L. YOCHELSON
}

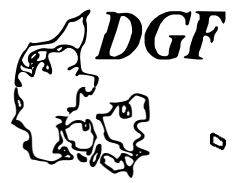

\begin{abstract}
Peel, J. S. \& Yochelson, E. L.: New information on Oelandia (Mollusca) from the Middle Cambrian of Sweden. Bull. geol. Soc. Denmark, vol. 36, pp. 263-273. Copenhagen, December, 31st, 1987

Additional specimens of Oelandia pauciplicata Westergård, 1936 from Öland, Sweden, confirm that this Middle Cambrian mollusc is asymmetrical in developing comarginal plications alternately on its lateral flanks. The specimens also show that at a late growth stage the species developed a tube near the apertural margin, below the overhanging apex, a feature not recorded in the orginal description. Oelandia is removed from the synonymy list of Latouchella Cobbold, 1921. The form and function of the alternating comarginal plications and the sub-apical tube are discussed.
\end{abstract}

John S. Peel, Geological Survey of Greenland, Østervoldgade 10, DK-1350 Copenhagen K, Denmark. Ellis L. Yochelson, Research Associate, Department of Paleobiology, National Museum of Natural History, Washington D. C. 20560, U.S.A., March 2nd, 1987.

Westergård (1936, pp. 25-26) described the laterally compressed, and bilaterally asymmetrical mollusc Oelandia pauciplicata as a new genus and new species of gastropod from the Middle Cambrian Paradoxides oelandicus beds of Öland, Sweden. His material was redescribed and reillustrated by Knight (1941, pp. 210-211, pl. 5, figs 3a-c). In a later work (Knight, 1952), Oelandia became the key genus for interpretation of a family-level group which subsequently came to be distinguished as the Superfamily Helcionellacea Wenz, 1938 by Knight et al (1960), although these authors placed Oelandia as a junior subjective synonym of the bilaterally symmetrical Latouchella Cobbold, 1921. This latter genus was not described by Knight $(1941,1952)$ or by Wenz (1938-44).

The concept which Knight (1952) applied to Oelandia corresponds more closely to Latouchella, particularly with regard to the bilateral symmetry. This synonymy, however, has been accepted by most subsequent workers (see, for example, Rozanov et al, 1969), although Rasetti (1957) had warned against including bilaterally symmetrical American forms together with the bilaterally asymmetrical Oelandia. Robison (1964) concurred with Rasetti and objected to Oelandia being placed in the synomymy of $\mathrm{La}$ touchella, as had been proposed by Knight et al (1960). Runnegar \& Jell (1976, p. 127) compared the type species of Oelandia to specimens assigned by them to Latouchella sp. indet. (Run- negar \& Jell, 1976, fig. 10B, 4-7) and considered to be probably apical internal moulds of a $\mathrm{La}$ touchella similar to L. merino Runnegar \& Jell, 1976. Runnegar \& Jell accepted the synonymy of Oelandia with Latouchella advocated by Knight et al (1960) but Geyer (in press) considered this to be uncertain.

Recently, additional specimens of Oelandia pauciplicata have been found in the palaeontological collections of the Geological Institute, University of Lund, Sweden. The specimens confirm one of the most characteristic features of Oelandia, but one considered without generic significance by those authors who have placed $O e$ landia as a junior subjective synonym of Latouchella. The distinctive feature is an alternation during growth of the coarse comarginal plications from one side of the shell to the other. The alternation produces the bilateral asymmetry originally described by Westergård (1936). It provides a clear point of difference with other helcionellaceans of the Latouchella-type where individual plications are equally developed on each lateral area to produce a bilaterally symmetrical shell.

In addition, two of the additional specimens retain a previously undescribed short spike on the internal mould, located near to the apertural margin, below the overhanging apex. The spike is interpreted as the infilling of a narrow cylinder or tube. A similar feature is also present in a specimen from the Middle Cambrian of Morocco described by Geyer (1986) as a new species of $L a$ - 

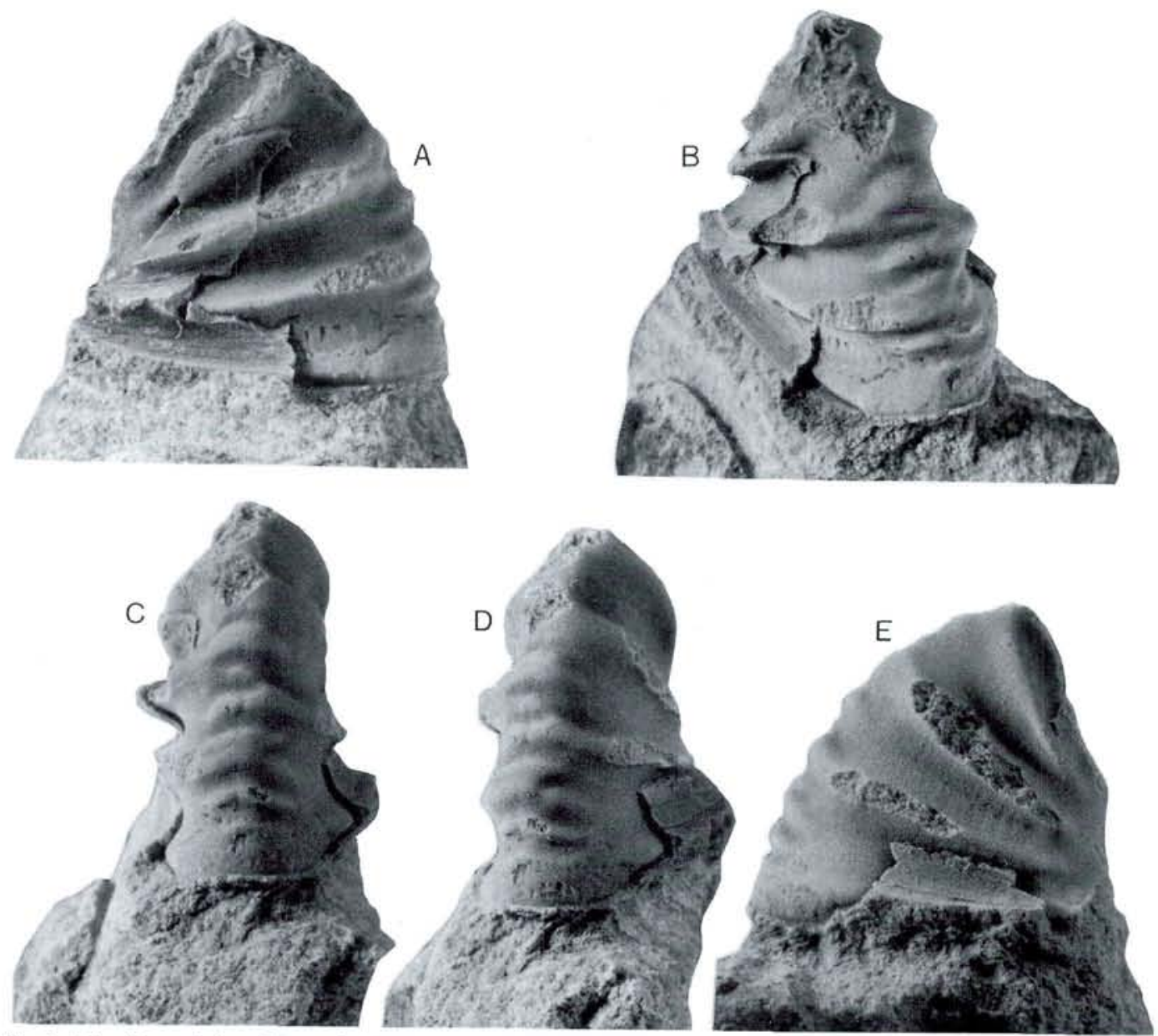

Fig. 1. Oelandia pauciplicata Westergård 1936, paratype, specimen number SGU Type 711 in the type collection of the Geological Survey of Sweden (SGU), Uppsala. Middle Cambrian, Öland, Sweden, $\times 6$. Largely exfoliated but uncrushed specimen without trace of a snorkel on the damaged sub-apical surface (left in fig. A). Five views from one lateral area around the dorsum to the other lateral area showing the discontinuous comarginal plications (preserved as rugae on the internal mould) which are developed alternately on the respective lateral areas. The plications interdigitate at the dorsum where smaller plications are also present.

touchella. The structure can be compared with the open tube or snorkel described in Yochelcionella Runnegar \& Pojeta, 1974, originally described from the Middle Cambrian of Australia but now known to occur in Lower to Upper Cambrian strata at many localities throughout the world (Runnegar \& Pojeta, 1974, 1980; Runnegar \& Jell, 1976; Pojeta \& Runnegar, 1976; Peel, 1980; Missarzhevsky \& Mambetov, 1981; Pei, 1985; Berg-Madsen \& Peel, 1987).

The new material has promoted a redescription of Oelandia, which is reinstated as a genus separate from Latouchella, and a discussion of both the function of the alternating comarginal plications and the marginal tube.

\section{Systematic Palaeontology}

Oelandia pauciplicata Westergård, 1936

Figures 1, 2

1929. Helcionella pauciplicata Westergård, p. 7 (nom. nud.)

1936. Oelandia pauciplicata Westergård, pp. 25-26, pl. 8, figs 6,7.

1941. Oelandia pauciplicata, Knight, pp. 210211, pl. 5, figs 3a-c.

Description. - The type specimens of this species are well described by both Westergård (1936) and by Knight (1941). Both authors noted the essen- 

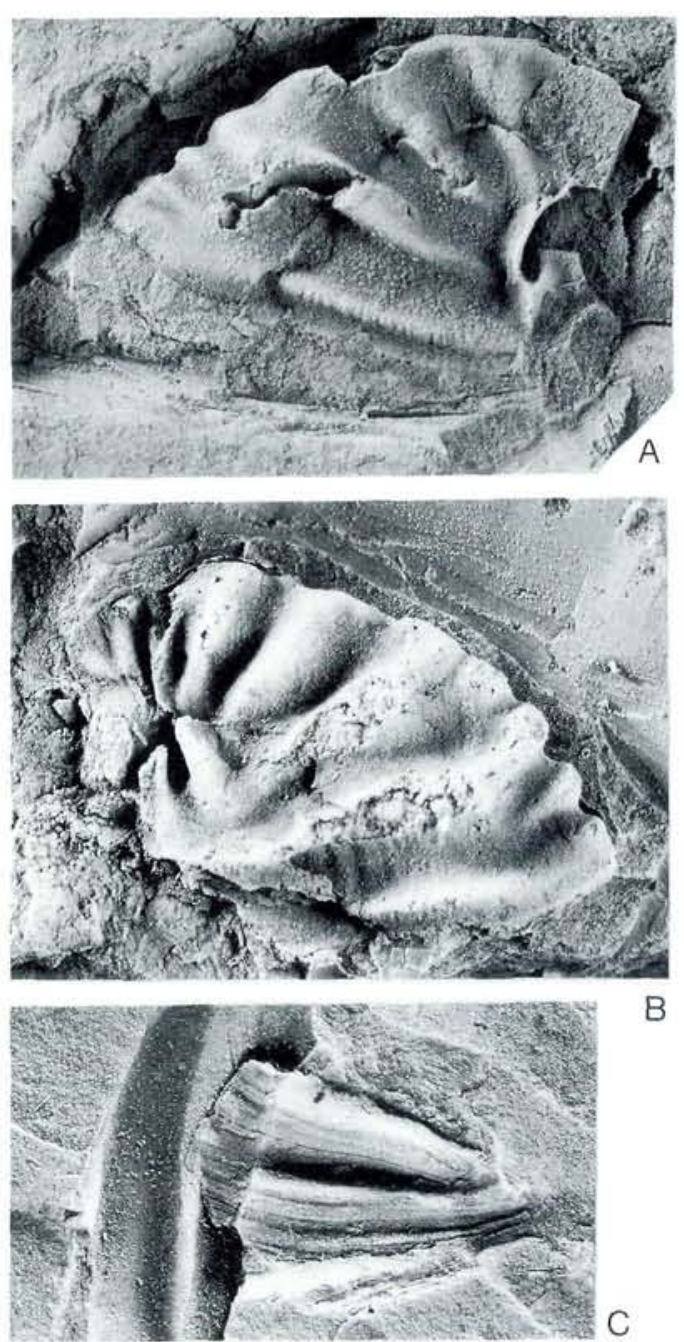

Fig. 2. Oelandia pauciplicata Westergărd 1936, Middle Cambrian, Öland, Sweden. Specimens preserved under the numbers LO $5757 \mathrm{t}$ to LO $5759 \mathrm{t}$, respectively, in the type collection. Department of Historical Geology and Palaeontology, Geological Institute, University of Lund, Sweden. A, B two internal moulds shown in lateral view, but with opposite sides preserved, showing the spike on the sub-apical surface interpreted as a sediment-filled tube ("snorkel"), $\times 6$. The apex is missing in both specimens. Comarginal plications (rugations on the internal mould) from the side buried in the matrix in both specimens are visible near the dorsum (compare A with Fig. ID. E and $B$ with Fig. 1A-C). C. external mould of fragment showing the fine growth lines, $\times 3$.

tial features of the high, laterally compressed shell and the alternating comarginal plications on the lateral areas (Fig. 1). The additional material conforms to this description but also retains details of the shell apertural margin not preserved in the type suite. A sub-cylindrical spike on the internal mould indicates that a short, stout tube was directed upwards, away from the plane of the aperture (Fig. 2A, B). This tube was apparently closed at its outer (adapical) end at the time of formation of one of the two internal moulds described here (Fig. 2A). This area is not preserved, apparently on account of breakage, in the figured paratype (compare Figs $1 \mathrm{E}$ and $2 \mathrm{~A}$ ).

Material. - Westergård (1936, p. 26) reported his material as being derived from the "Zones of Par. insularis and Par. pinus" which together now comprise the Eccaparadoxides oelandicus Stage of the Middle Cambrian. The author's only indication of abundance was to state that the species was very rare. The holotype, preserved in shale, is stated to have come from a depth of 3.5 $\mathrm{m}$ in a well dug at Borgholm in 1889. The paratype (Fig. 1) is preserved in limestone and was collected by von Schmalensee in 1881, at Stora Frö, a locality about $15 \mathrm{~km}$ south of Borgholm.

The additional specimens (Fig. 2) bear number 76 of the Swedish Cambrian Collection of the Geological Institute, University of Lund, although they are now preserved in the type collection of the same institute under the numbers LO $5757 \mathrm{t}$ to LO $5759 \mathrm{t}$, inclusive. Three labels accompanying the specimens indicate that they were collected by von Schmalensee in 1899, from the top of the Eccaparadoxides oelandicus Stage, Borgholm, Öland, about $2 \mathrm{~m}$ below the top of the stage; this corresponds to the internationally recognised zone of Ptychagnostus praecurrens. The two most complete specimens were identified to species on one of the labels by Professor Gerhard Regnéll. Both these individuals are internal moulds which have been laterally crushed in shale; in the past, they have been partially excavated free from the surrounding matrix. The specimens lack growth lines on account of their preservation as internal moulds, but an accompanying fragment preserved on the obverse of the slab with the larger of the two complete specimens (Fig. 2B) shows closely spaced growth lines (Fig. 2C).

Remarks. - Knight (1941, p. 211) described Oelandia pauciplicata as possessing comarginal plications alternating in position from one side to the other, a feature suggested by his illustrations of the paratype (Knight, 1941, pl. 5, fig. 3c) and even more evident from the series of photographs of the same specimen presented here in Fig. 1. The two complete specimens collected in 1899 


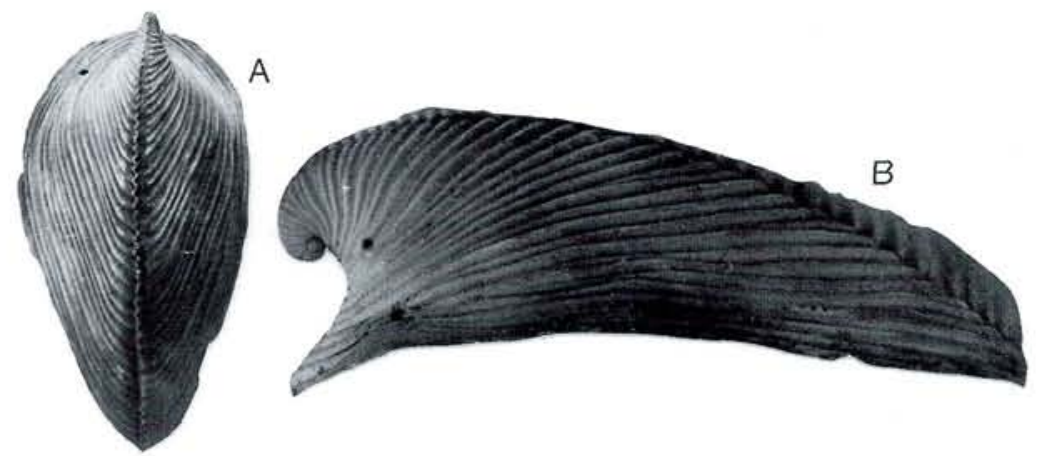

Fig. 3. Carinaria Lamarck 1801. The thin shell of this present day atlantacean heteropod (Class Gastropoda; Opisthobranchia), shown here in dorsal view (left, $\times 1$ ) and lateral view (right, $\times 1.8$, showing the minute, helically coiled nucleus) was compared to Oelandia by Westergård (1936). For discussion see text.

each show an opposite lateral side but, despite the crushing, it is clear that each specimen also possesses alternating plications. Individual plications are fully developed on only one side of the shell and die out abruptly just after passing around the dorsum (the convex face in lateral view, as in Figs 2A, B) on to the other side of the shell.

Examination of the paratype indicates that additional minor plications occur between the major alternating plications just in the dorsal region (Fig. 1C, D).

Westergård commented on the similarity between alternating plication in Oelandia and in the recent Carinaria Lamarck, 1801 (Fig. 3). The latter is an extremely thin-shelled atlantacean gastropod, with coiled early whorls and a rapidly expanding final half whorl, which is superficially similar to Oelandia. In detail, however, the two shells and their respective styles of plication are quite distinct. In Carinaria, plications on each side of the shell are much more numerous and of lower relief than those in Oelandia. They do not pass around the dorsum from one lateral area to the other, but terminate as corrugations in the median dorsal carina (in life, this surface is actually ventral in the pelagic Carinaria). The two shells also differ in terms of the proportions of the expanded final growth stage. In Carinaria, the shell is commonly widest below the overhanging apex and tapers toward the acute, carinate, dorsal, surface. In Oelandia, the width of the shell is more constant and the dorsal surface more uniformly rounded.

Examination of the paratype of Oelandia pauciplicata indicates that the internal expression of the plications, as seen in counterpart form on the internal mould, does not differ significantly from that seen on the shell exterior (Figs 1B, C, D); the shell is of uniform thickness. However, as might be expected, the outer edge of the plications as expressed in the shell is somewhat sharper than on the internal mould, where the outer edge of each plication is more uniformly rounded.

\section{Comparison with other species}

Oelandia is distinguished from Latouchella and the variety of other genera of plicate helcionellaceans described in recent years (see summary by Runnegar \& Jell, 1976) by its alternation of comarginal plications from one lateral area to the other during growth.

Latouchella jingheensis Yü \& Ning, 1985 from the Middle Cambrian Kensayi Formation of Jinghe, Xinjiang, People's Republic of China is transferred to Oelandia. The species is apparently known from a single specimen about $3 \mathrm{~mm}$ in length, about one third of the size of the available specimens of Oelandia pauciplicata from Sweden. The illustration of the holotype of $O$. jingheensis suggests an early growth stage (Yü \& Ning, 1985, pl. 1, figs 9, 10); the rate of shell expansion is greater than in $O$. pauciplicata and the transverse plications are more numerous. The lateral inconsistency of plications from one lateral area of the shell to the other was remarked upon by Yü \& Ning (1985, p. 49) and is clearly evident in their illustrations. It is less perfectly developed than in $O$. pauciplicata but this may be in part a function of the small size of the available specimen of $O$. jingheensis. Yü \& Ning (1985) 
compared their species with $O$. pauciplicata, which they considered to be a species of $L a$ touchella.

Latouchella comma Geyer, 1986, from the Middle Cambrian of Morocco is also transferred to Oelandia. In this species individual comarginal elements show less relief on the internal mould than in $O$. pauciplicata. Plications do not appear to cross the dorsum and the minor mid-dorsal plications noted in $O$. pauciplicata are absent. Geyer (1986) illustrated a sub-cylindrical spike on the sub-apical area of an internal mould of Oelandia comma but noted its absence in other specimens both of the same size and larger. According to Geyer, the spike in O. comma is well constrained at both ends and the sub-apical termination was not an open tube at the time of fossilisation. In specimens where the spike on the internal mould is not developed, the corresponding area of the shell margin is extended and a deep sinus is developed.

Those helcionellaceans which bear true snorkels show a variety of morphologies varying from tall cones with oval to sub-circular cross-sections, e.g. Yochelcionella ostentata Runnegar \& Jell, 1976 , to more strongly curved, laterally compressed forms such as $Y$. americana Runnegar \& Pojeta, 1980. Oelandia pauciplicata is readily distinguished from described species on account of its large size, alternating comarginal plications and marginal location of its sub-apical tube. In described species of snorkel-bearing helcionellaceans, the snorkel appears at an ontogenetically earlier growth stage than the sub-apical tube of Oelandia and thus appears to be located relatively higher on the shell.

\section{Functional significance of plication}

The function of plication, whether the coarse, alternating comarginal plication present in $\mathrm{Oe}$ landia or the symmetrical plication of other helcionellaceans, is uncertain. Plication clearly serves to strengthen the shell against crushing but the coarseness of the individual plications in $\mathrm{Oe}$ landia and related forms suggests that this was not their principal function.

As noted above, the rounded rugae on the internal mould of $O$. pauciplicata correspond to sharper, somewhat lamellose ribs on the outside of the plicate shell. Grossly similar lamellose, concentric, but non-plicate shell structural elements as those present on the shell exterior also occur in a number of bivalves, such as the recent Chione. Stanley (1970) noted that bivalves with this form of prominent ornamentation are slower burrowers than many smooth forms. Thus, plication in Oelandia, if comparable in function to the shell ornamentation of these bivalves, would not seem to be an adaptation to active burrowing, although the laterally compressed form may suggest a mode of life partly buried below the sediment surface. In this respect, the strongly ornamented exterior may help anchor the apertural regions of Oelandia in the sediment or, in association with a gentle rocking movement, assist the process of embedding. Again, the dimensions and broadly rounded form of the plications in many helcionellaceans seem excessive if this is their sole purpose; rugose or lamellose surface ornamentation (as in Chione) might be expected to better achieve this embedding function.

It is concluded that development of the large comarginal plications to a large extent reflects the internal organisation of helcionellaceans, although the presence of various types of plication within the group may suggest association with a variety of different anatomical structures or functions. Plications in some morphological types may be associated with periodic slight expansion of the aperture due to episodic growth. As such, the plications could reflect successive positions of the aperture, indicating more stable periods in the growth history of the shell. Intervening nonplicate areas would thus be produced by periods of relatively rapid shell growth. Examination of growth increments should help to test this hypothesis but available material of $O$. pauciplicata is not well suited to this purpose.

It is not suggested, however, that the coarse plication is merely an 'accidental' bi-product of periodic apertural expansion. In many helcionellaceans, e.g. Latouchella merino Runnegar \& Jell, 1976 as illustrated by Runnegar \& Jell (1976, fig. 9D), the plications form pronounced outpouchings of the shell which terminate abruptly on the lateral flanks near the sub-apical surface. Some examined helcionellacean material showing this morphology gives the impression that the outpouching occurs slightly before a growth stage with concentration of growth lines, i.e. that the 
aperture of the helcionellacean is slightly constricted during the more stable period of growth, rather than slightly flared as noted in other forms, above. In this case, the outpouching could be an acquisition to increase mantle cavity efficiency during these more stabile periods in the growth history of the helcionellacean.

Further evidence in favour of an association of coarse comarginal plication with internal organisation is provided by an illustration of a helcionellacean given by Runnegar (1985, fig. 1A, see also Runnegar \& Pojeta 1985, fig. 6). The specimen has a smooth outer shell surface but substantial thickening of the shell interior has produced constrictions of the shell interior visible as U-shaped channels on the internal mould. Areas of high relief between the comarginal constrictions form coarse rugae on the internal mould. The specimen figured by Runnegar was obtained from the Lower Cambrian Parara Limestone of South Australia, but similar specimens are also known from the Lower Cambrian of North Greenland (J. S. Peel, unpublished observation). Transverse constrictions also occur in bellerophontiform molluscs, e.g. Anapetopsis Peel, 1975, described from the Late Silurian of Nova Scotia (Peel, 1975, 1978), but their purpose is also unexplained.

The significance of the alternation of comarginal plications from one lateral area to the other remains arcane. It can be seen from Fig. $1 C$ that the width of the aperture in Oelandia is maintained even though its position varies slightly from one side to the other, with growth. This is in contrast to those helcionellaceans with symmetrical plication, where the aperture is periodically expanded and constrained. Alternating plication was adopted briefly in the Middle Cambrian but its absence in the great majority of helcionellaceans suggests that the adaptation was not a general success.

\section{The marginal tube}

Two of the additional specimens of Oelandia pauciplicata described here (Fig. 2) show a sub-cylindrical spike on the sub-apical surface of the internal mould near the aperture (a feature not referred to in previous descriptions or discernible in published illustrations of the type specimens).
In Fig. 2A the spike rises almost perpendicular from the plane of the aperture twoard the earlier coiled portion of the shell (the apex is missing in this specimen). The spike is compressed laterally and narrows slightly in cross-section ad-dorsally, i.e., on the side bounded by a pronounced notch which separates the spike from the rest of the internal mould of the whorl. The uppermost (abapertural) termination of the spike is flattened; although partly broken, it retains small smooth areas moulding the shell interior. The sediment surrounding the internal mould retains a weak impression of the spike which continues beyond its preserved termination for some distance toward the now broken away apex.

General configuration strongly suggests that the spike represents a sediment-filled tube and that the tube was closed at some distance from its outer end by a plug of shell material or septum (or series of septa) at the time of formation of the internal mould. Thus, the sediment which forms the present spike-like internal mould must have entered the tube via the shell interior.

The specimen illustrated in Fig. 2B shows the spike less perfectly but there is also some evidence from surrounding sediment that the spike was longer than currently preserved. The spike rises from a continuation of one of the comarginal swellings on the internal mould which forms the inner surface of a comarginal plication of the shell. Similarly, the deep cleft separating the spike from the rest of the whorl represents the continuation on the internal mould of one of the broad concave gutters between consecutive swellings. Again, the general configuration of the spike suggests a tube filled with sediment, but it is not possible to establish if the tube was closed or open at the time of fossilisation.

By analogy with Yochelcionella, the short, stout tube in $O$. pauciplicata is interpreted as a snorkel. It is acknowledged, however, that the tube as preserved in at least one of the new specimens of $O$. pauciplicata and in Geyer's $O$. comma was closed at the time of fossilisation. Thus, it is envisaged that the snorkel did not function throughout the life of the individual specimens but that at a later growth stage its function was better served by other configurations of the mantle cavity. The suite of specimens illustrated by Geyer (1986) demonstrates that the snorkel was a transient feature which lost its func- 
tion when the large sub-apical sinus was developed. Indeed, it would appear that not all individuals developed a snorkel, but that some may have developed the sub-apical sinus directly.

Similar variability in the development of shell morphological features associated with mantle cavity currents entering or leaving the shell is also known in the bellerophontiform molluscs. For example, Peel $(1974,1977)$ noted that only some specimens of Plectonotus Clarke, 1899 and Tritonophon Öpik, 1953 in samples from the Silurian Arisaig Group of Nova Scotia showed well developed dorso-lateral emarginations interpreted as indicating the loci of inhalant water currents, although the water currents must logically have been present in all individuals.

The fact that the sub-apical tube in both $O$. pauciplicata and $O$. comma is closed in preserved specimens provides an apparent contradiction to the proposed interpretation as a snorkel of the type seen in Yochelcionella. A comparable situation is seen in many gastropods, however, both living and fossil, where spines and channels are developed at the apertural margin and are subsequently sealed off by a plug of shell material as growth proceeds. In muricids, for example, varicose arrays of spines commonly are developed at every third of a whorl, possibly reflecting association with shell stability by increasing the width of the base of the shell in its life position, that is with the aperture facing down to the sediment surface. Internal moulds may retain the ontogenetically latest suite of spines or channels, in the form of spikes of sediment of the type seen in the presently described specimens of $O$. pauciplicata, but all trace of earlier spines commonly is lost. Many of these spines in gastropods are not primarily associated with mantle cavity currents and this is also the general case in muricids. In some species of that group the reflexed anterior tip of the inhalant (= siphonal) canal is also partially abandoned as the shell grows rapidly to its next stable position.

The Carboniferous (Pennsylvanian) bellerophontiform mollusc Knightites Moore, 1941 also abandons and seals off its paired dorsal inhalant channels with later growth (Knight, 1952; Peel, 1974). Thus, the sub-apical tube in Oelandia may have functioned only as an open conduit for water transport for a relatively short period in ontogeny. A tube might not even have been devel- oped in some specimens (as appears to be the case with $O$. comma), while its function in others was quickly taken over by the prominent emargination in the apertural margin beneath the apex.

The tube in Oelandia differs from that in Yochelcionella in being located near the apertural margin. The snorkel in most species of the latter genus is located high on the sub-apical wall and tends to have a relatively larger diameter, when compared to the other dimensions of the shell. In Eotebenna Runnegar \& Jell, 1976 the snorkel is not a perfect tube, but its opening is connected to the shell aperture by a narrow slit.

The tendency for a cleft to develop on the internal mould below the apex in connection with comarginal undualtions is not confined to Oelandia. A superficially similar structure is seen in the previously mentioned, un-named helcionellacean figured by Runnegar (1985). In this form, the cleft visible on the sub-apical surface when viewed in lateral aspect is produced by a varix on the shell interior. This varix produces a comarginal constriction on the internal mould and the cleft is not visible on the shell exterior. This contrasts with the interpreted situation in Oelandia pauciplicata where the cleft is a feature of both the shell and the internal mould, separating the tube from the sub-apical surface. The specimen figured by Runnegar shows no indication of a tube of the type seen in $O$. pauciplicata. Subsequent to the constriction on the internal mould which produces the cleft on the sub-apical surface, the shell in the Australian species regains its normal rate of expansion.

An alternative interpretation, not accepted here, is that the upward extension of the internal mould in $O$. pauciplicata is not a tube but merely matrix trapped between the concave outer shell wall and an internal plate. This plate would diverge from the inner surface of the sub-apical, concave outer shell wall and produce a deep slot on a mould of the shell interior. A similar plate is characteristic of ribeiriid rostroconchs where it is termed a "pegma". Pojeta \& Runnegar (1976, p. 47) defined the pegma of the ribeiriids as a "plate connecting [the] right and left valves in [the] umbonal part of [the] shell" and functioning as a support for large muscles. A pegma is strongly developed, for example, in Technophorus Miller, 1889 (see Pojeta \& Runnegar, 1976, pl. 13, particularly figs. 9-12) and can serve to isolate a seg- 

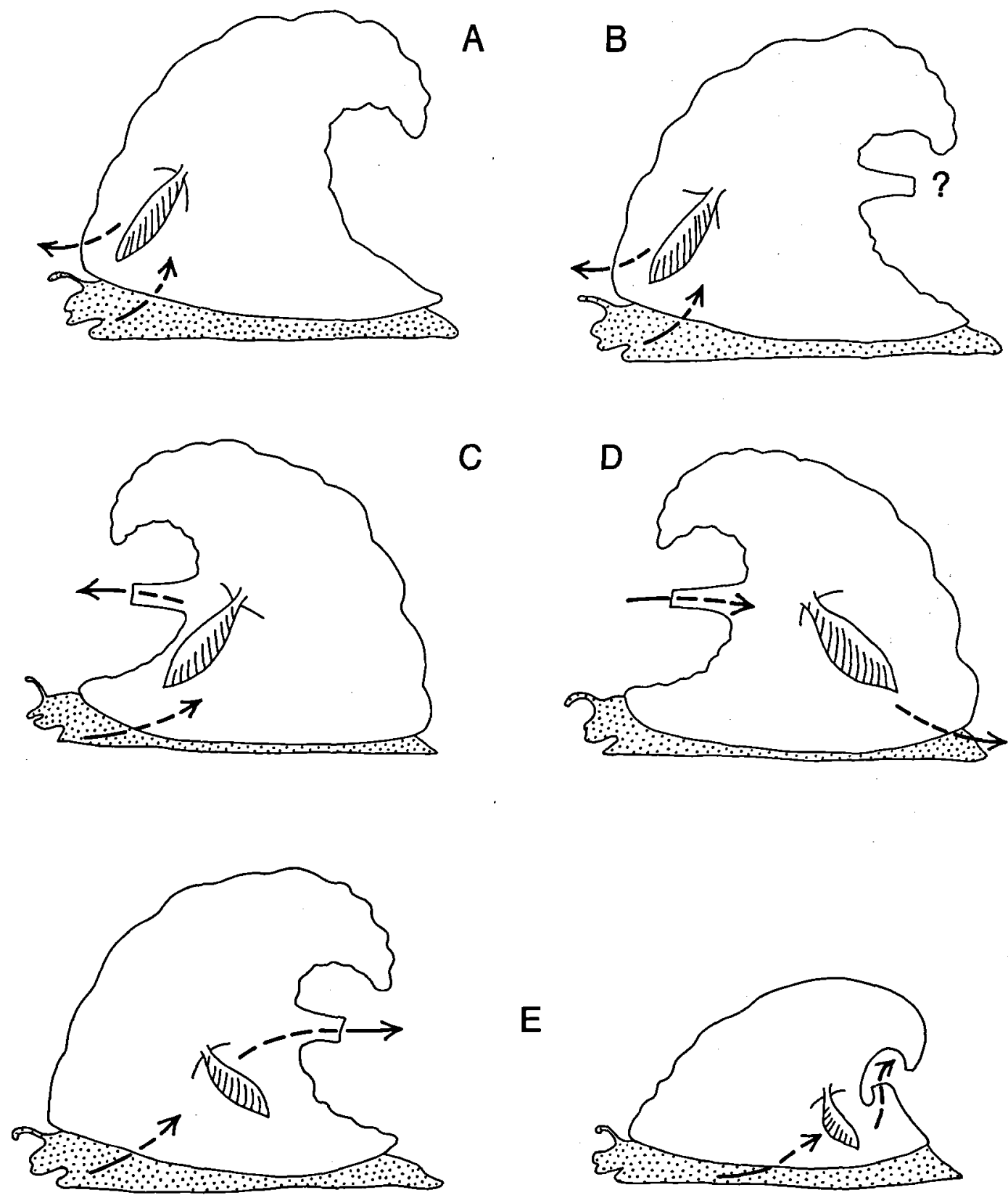

E

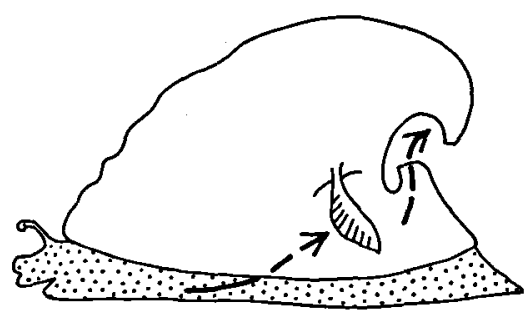

Fig. 4. Possible reconstructions of water currents in the helcionellaceans Latouchella, Yochelcionella and Oelandia. A, Latouchella reconstructed as a gastropod. Knight (1952) postulated that water currents in the torted mollusc entered the mantle cavity antero-laterally and united prior to exhalation in the median dorsal area. Snorkel-bearing helcionellaceans were not known to Knight. $\mathrm{B}$, Yochelcionella interpreted as a torted molluse in the manner suggested by Knight (1952). The function of the posterior snorkel is not known, but it is not associated with respiration. C, Yochelcionella interpreted as a torted mollusc but with the anterior snorkel forming an exhalant conduit. D, Yochelcionella interpreted as an untorted mollusc with the anterior snorkel housing the inhalant stream. This is the reconstruction accepted by Pojeta \& Runnegar (1976). E, Yochelcionella (left) and Oelandia (right) interpreted as untorted molluscs with the posterior snorkel containing the exhalant stream. This is the reconstruction favoured by Geyer (1986) and ourselves. Modified from Pojeta \& Runnegar (1976, fig. 9). 
ment of the internal mould which at least superficially resembles the spike-like structure visible in Oelandia. Runnegar (1983) and Runnegar \& Pojeta (1985) have illustrated a similar cleft in an internal mould of the univalved Anabarella and suggested that this structure may be homologous with the rostroconch pegma. It would appear that this structure in the internal mould of Anabarella parallels the situation described by Geyer (1986) in Oelandia comma where specimens not showing the sediment-filled tube often retain a prominent ridge-like extension of the internal mould on the sub-apical wall corresponding to a broad sinus with flared margins in the original shell aperture. Some of Geyer's illustrated specimens show a small tubercle representing a trace of the sediment-filled tube on the upper surface of this ridge-like extension. A similar minor tubercle is also visible in the specimen of Anabarella illustrated by Runnegar \& Pojeta (1985, fig. 20).

\section{Function of the snorkel}

The function of the snorkel in Yochelcionella was reviewed in some detail by Pojeta \& Runnegar (1976, fig. 9) who concluded that it served as a conduit for a water current either entering or leaving the mantle cavity. Possible interpretations varied from an inhalant function, with the snorkel located anteriorly above the head, to an exhalant canal, located either anteriorly or posteriorly (fig. 4). Pojeta \& Runnegar concluded that the most satisfactory interpretation placed the snorkel at the anterior, with an inhalant function (fig. 4A). This interpretation is in agreement with a phylogenetic model for the Mollusca proposed by Runnegar \& Pojeta (1974) and developed in a series of subsequent papers by the same authors (see Runnegar \& Pojeta, 1985 for references). In particular, the model of mantle cavity water circulation patterns suggested for Yochelcionella and helcionellaceans in general, closely resembles that proposed for the ribeiriid rostroconchs, which Runnegar \& Pojeta consider to be descended from the helcionellaceans (Pojeta \& Runnegar, 1976, fig. 9).

Runnegar \& Pojeta (1974) proposed a morphological sequence from helcionellaceans through Heraultipegma Pojeta \& Runnegar, 1976 to the ribeiriid rostroconch Ribeiria Sharpe, 1853. He- raultipegma was considered by Pojeta \& Runnegar (1976) to be a ribeiriid rostroconch but MacKinnon (1985) has questioned this assignment, noting that Heraultipegma may not be a rostroconch but a rostroconch-like, laterally compressed monoplacophoran, a helcionellacean in the present usage. He further commented that his re-interpretation of Heraultipegma considerably increased the phylogenetic gap between laterally compressed helcionellaceans and the rostroconchs.

It is thus a natural speculation that helcionellaceans and rostroconchs may not be phylogenetically related. This interpretation would negate the need for uniformity of water circulation patterns proposed by Pojeta \& Runnegar (1976). Released from the limitations imposed by the model, the snorkel in Yochelcionella can be ascribed other functions than the anteriorly located conduit for an inhalant stream proposed by Pojeta \& Runnegar (fig. 4D). Geyer (1986) accepts one of the models of shell orientation and water circulation rejected by Pojeta \& Runnegar (1976, fig. 9) in considering the snorkel to be located posteriorly and to house an exhalant current (fig. 4E).

The two theories concering shell orientation and water circulation patterns in Yochelcionella require diametrically opposite interpretations (compare $\mathrm{D}$ and $\mathrm{E}$ in fig. 4) although both consider helcionellaceans to be untorted molluscs, a view with which we concur. In this respect, both differ from the reconstruction suggested by Knight (1952) who considered helcionellaceans to be torted, hence gastropods (fig. 4A). The currently described material from the Middle Cambrian of southern Sweden suggests that $O e$ landia was anatomically organised in the same way as Yochelcionella, but does not contribute significantly to the further understanding of mantle cavity structure in helcionellaceans.

Water currents broadly analagous to those proposed by Geyer in helcionellaceans, with inhalant streams entering the mantle cavity on either side and uniting prior to median exhalation, are described from living pleurotomariacean gastropods and inferred in extinct bellerophontiform molluscs (although the direction of exhalance relatively to the inhalant currents clearly differs, dependent on the presence or absence of torsion). Members of the latter group are variously 
considered to be torted (hence gastropods), untorted or a mixture of both torted and untorted forms (see discussion and references in Yochelson, 1967; Harper \& Rollins, 1982; Peel, 1974, 1985). Most bellerophontiform genera show a deep median dorsal emargination, always interpreted as an exhalant sinus no matter whether the group is considered to be torted or not. The deepest portion of the emargination in many genera of bellerophontiform molluscs and in the pleurotomariin gastropods is parallel-sided and forms a true slit. A few even close the slit periodically, producing a circular or elongate hole, a trema, through which the exhalant stream passes. This trema can be considered to be analagous to the snorkel of Yochelcionella and Oelandia, although the perforation of the shell in these genera is extended into a long tube open at its outer end. Development of the tube, which may be enormous in some specimens of Yochelcionella (cf. Runnegar \& Jell, 1980, fig. 1), serves to increase the degree of physical separation between the de-oxygenated exhalant stream and the laterally-disposed inhalant streams of clean water. The development of the snorkel in Yochelcionella and Oelandia thus parallels the tendency seen in many pleurotomariin gastropods and bellerophontiform molluscs for the slit to increase in depth.

With a background in studies of these primitive gastropods, monoplacophorans and bellerophontiform molluscs we therefore tend to support Geyer (1986) in considering the snorkel in $\mathrm{Yo}$ chelcionella and Oelandia to have been placed posteriorly and to have served an exhalant function (fig. 4E).

Acknowledgements. Jan Bergström (Lund) provided information on Middle Cambrian stratigraphy. Gerd Geyer (Würzburg) kindly supplied information from his unpublished studies of Middle Cambrian molluscs. Both are thanked for their comments to an earlier version of the manuscript. Peel publishes with permission from the Director, Geological Survey of Greenland.

\section{Dansk sammendrag}

Oelandia Westergård, 1936 (Mollusca) fra Mellem Kambrium i Sverige revideres og genetableres som en selvstændigt slagt. Det karakteristiske ornament beskrevet af Westergård (1936) bekræftes. En rør-formet 'snorkel' beskrives for første gang i Oelandia og sammenlignes med en lignende struktur i Yochelcionella Runnegar \& Pojeta, 1974. Funktionen af snorklen i begge slægter diskuteres.

\section{References}

Berg-Madsen, V. \& Peel, J. S. 1987: Yochelcionella (Mollusca) from the late Middle Cambrian of Bornholm, Denmark. Bull. geol. Soc. Denmark 36, 259-261.

Geyer, G. 1986: Mittelkambrische Mollusken aus Marokko und Spanien. Senckenbergiana Leth. 67, 55-118.

Harper, J. H. \& Rollins, H. B. 1982: Recognition of Monoplacophora and Gastropoda in the fossil record: a functional morphological look at the bellerophont controversy. Proc. Third N. Am. Paleont. Conv. I, 227-232.

Knight, J. B. 1941: Paleozoic gastropod genotypes. Spec. Pap. geol. Soc. Am. 32, 510 pp.

Knight, J. B. 1952: Primitive fossil gastropods and their bearing on gastropod classification. Smithson. Misc. Collns 117, $13,56 \mathrm{pp}$.

Knight, J. B., Cox, L., R., Keen, A. M., Smith, A. G., Batten, R. L.; Yochelson, E. L., Ludbrook, N. H., Robertson, R., Yonge, C. M. \& Moore, R. C. 1960: In Moore, R. C. (edit.) Treatise on Invertebrate Paleontology I, Mollusca 1. Lawrence: Geol. Soc. Am. \& Univ. Kansas, 351 pp.

Mackinnon, D. I. 1985: New Zealand late Middle Cambrian molluscs and the origin of Rostroconchia and Bivalvia. Alcheringa 9, 65-81.

Missarzhevsky, V. V. \& Mambetov, A. J. 1981: Stratigraphy and fauna of Cambrian and Precambrian boundary beds of Maly Karatau. Trudy Geol. Inst. Akad. Nauk SSSR 326, 92 pp.

Peel, J. S. 1974: Systematics, ontogeny and functional morphology of Silurian trilobed bellerophontacean gastropods. Bull. geol. Soc. Denmark 23, 231-264.

Peel, J. S., 1975: Anapetopsis, a new late Silurian Gastropod from Nova Scotia. Can. J. Earth Sci. 12, 509-513.

Peel, J. S. 1978: Faunal succession and mode of life of Silurian gastropods in the Arisaig Group, Nova Scotia. Palaeontology 21, 285-306.

Peel, J. S. 1980: Yochelcionellids from the Early and Late Cambrian of North Greenland. Rapp. Grønlands geol. Unders. 101, 44 (only).

Peel, J. S. 1984: Autecology of Silurian gastropods and monoplacophorans. Spec. Pap. Palaeontology 32, 165-182.

Pei Fang 1985: First discovery of Yochelcionella from the Lower Cambrian of China and its significance. Acta Micropalaeontologica Sinica 2, 395-400. [in Chinese with English summary].

Pojeta, J. \& Runnegar, B. 1976: The paleontology of rostroconch mollusks and the early history of the phylum Mollusca. U. S. geol. Surv. Prof. Pap. 968, 88 pp.

Rasetti, F. 1957: Additional fossils from the Middle Cambrian Mt. Whyte Formation of the Canadian Rocky Mountains. J. Paleont. 31, 955-972.

Robison, R. A. 1964: Late Middle Cambrian faunas from western Utah. J. Paleont. 38, 510-566.

Rozanov, A. Y., Missarzhevsky, V. V., Volkova, N. A., Voronova, L. G., Krylov, I. N., Keller, B. M., Korolyuk, I. K., Lendzion, K., Michniak, R., Pychova, N. G. \& Sidorov, A. D. 1969: The Tommotian Stage and the problem of the lower boundary of the Cambrian. Trudy Geol. Inst. Akad. nauk SSR 206, 380 pp. [in Russian].

Runnegar, B. 1983: Molluscan phylogeny revisited. Mem. Assoc. Australas. Palaeontol. 1, 121-144.

Runnegar, B. 1985: Shell microstructures of Cambrian molluscs replicated by phosphate. Alcheringa 9, 245-257. 
Runnegar, B. \& Jell, P. A. 1976: Australian Middle Cambrian molluscs and their bearing on early molluscan evolution. Alcheringa 1, 109-138.

Runnegar B. \& Jell, P. A. 1980: Australian Middle Cambrian molluscs: corrections and additions. Alcheringa 4, 111113 .

Runnegar, B. \& Pojeta, J. 1974: Molluscan phylogeny; the paleontological viewpoint. Science 186, 311-317.

Runnegar, B. \& Pojeta, B. 1980: The monoplacophoran mollusk Yochelcionella identified from the Lower Cambrian of Pennsylvania. J. Paleont. 54, 635-636.

Runnegar, B. \& Pojeta, J. 1985: Origin and diversification of the Mollusca. In Trueman, E. R. \& Clarke, M. R. (edit.) The Mollusca, 10, Evolution, 1-57. London and Orlando: Academic Press.
Stanley, S. 1970: Relation of shell form to life habits in the Bivalvia (Mollusca). Mem. geol. Soc. Am. 125, 206 pp.

Wenz, W. 1938-44: Gastropoda, Allgemeiner Teil und Prosobranchier In Schindewolf, O. H. (edit.) Handbuch der Paläozoologie 6, 1639 pp. Gebrüder Borntraeger, Berlin.

Westergård, A. H. 1936: Paradoxides oelandicus beds of Öland with the account of a diamond boring through the Cambrian at Mossberga. Sver. geol. Unders. C, 394, $66 \mathrm{pp}$.

Yochelson, E. L. 1967:Quo Vadis, Bellerophon? In Teichert, R. C. \& Yochelson, E. L. (edit.) Essays in Paleontology and Stratigraphy, 141-161. Lawrence: Univ. Kansas.

Yü Wen \& Ning Hui 1985: Two Cambrian monoplacophorans from Borohore, Xinjiang. Acta Palaeontologica Sinica 24, 47-50. [in Chinese with English summary]. 